\title{
Coronary haemodynamic effects of short term intravenous administration of gallopamil in patients with stable exertional angina
}

\author{
STEFANO DE SERVI, MAURIZIO FERRARIO, STEFANO GHIO, \\ ANTONIO MUSSINI, LUIGI ANGOLI, EZIO BRAMUCCI, \\ ANTONELLA BARTOLI, * ERCOLE POMA, RENATO RONDANELLI, * \\ GIUSEPPE SPECCHIA
}

From the Divisione di Cardiologia, *Dipartimento di Farmacologia, Policlinico $S$ Matteo, Istituto di Ricovero e Cura a Carattere Scientifico, Pavia, Italy

SUMMARY The effects of short term intravenous administration of gallopamil on coronary haemodynamic variables were studied in 10 patients with stable exertional angina and angio- $\supset$ graphically confirmed coronary artery disease that affected the proximal portion of the left $\vec{\emptyset}$ anterior descending artery. Blood flow in the great cardiac vein was measured by a thermodilution. ${ }^{-}$ technique, both at rest and during ischaemia induced by atrial pacing, before and after intravenous administration of gallopamil $(0.02 \mathrm{mg} / \mathrm{kg}$ as a bolus dose given over three minutes, followed by an infusion of $0.0005 \mathrm{mg} / \mathrm{kg} / \mathrm{min}$ ). Gallopamil significantly prolonged the mean (SD)흔 duration of pacing that was tolerated $(11(2 \cdot 6)$ vs $14.8(2 \cdot 4)) \mathrm{min}$, significantly increased the mean (SD) peak heart rate attained during pacing (142(15) vs 158(11) beats $/ \mathrm{min}$ ), and reduced mean (SD) arterial pressure (133 (17) vs 116 (17) $\mathrm{mm} \mathrm{Hg}$ ). There were no changes in mean (SD) blood $\overrightarrow{\overrightarrow{0}}$ flow in the great cardiac vein $(134.1$ (57) vs 112.9 (38) $\mathrm{ml} / \mathrm{min}$, mean (SD) anterior regional coronary resistance $(1.18(0.6)$ vs $1.15(0.5) \mathrm{mm} \mathrm{Hg} / \mathrm{ml} / \mathrm{min})$, and mean (SD) anterior regional myocardial oxygen consumption $(16.6$ (6) vs 13.7 (4) $\mathrm{ml} / \mathrm{min})$.

These data confirm that gallopamil is an effective antianginal agent and suggest that a reduction of myocardial oxygen demand is the predominant mechanism by which the drug exerts its? beneficial effects.

The antianginal efficacy of calcium channel blocking agents such as verapamil,,$^{1-3}$ nifedipine, ${ }^{4-6}$ and diltiazem ${ }^{7-9}$ is well established. The mechanism of the effect depends on the affinity of the agent for its receptor sites and the cause of ischaemia, and is achieved by a reduction in myocardial oxygen consumption by an improvement in oxygen supply or both.

New calcium channel blocking agents are being developed to improve the efficacy and safety of antianginal action. One of these new calcium antagonists, gallopamil, a verapamil analogue, improved

Requests for reprints to Dr Stefano De Servi, Divisione di Cardiologia, Policlinico S Matteo, 27100 Pavia, Italy.

Accepted for publication 3 November 1986 exercise tolerance in patients with stable exertional 0 angina. ${ }^{10-12}$ There is evidence that gallopamil exerts its antianginal effect by improving the ratio of myocardial oxygen supply to oxygen demand. But the mechanism of this action has not been eluci-o dated.

We studied 10 patients with stable exertional angina and angiographically confirmed disease of the proximal portion of the left anterior descending coronary artery. Thermodilution measurements of blood flow in the great cardiac vein-that is the venous efflux from the territory supplied by the left 0 anterior descending artery ${ }^{13}$-were taken at rest ando during myocardial ischaemia induced by rapid atrial ${ }_{\odot}^{\Phi}$ pacing both before and after the short term intra- $\overrightarrow{\mathbb{D}}$ venous administration of gallopamil. The effects of $O$ the drug on pacing tolerance were then related to 
coronary haemodynamic changes in the anterior region of the heart in which perfusion was jeopardised.

\section{Patients and methods}

\section{PATIENTS}

We studied 10 patients (nine men and one woman, mean age 54 years) with stable exertional angina. They all had a positive exercise test, defined as the development of typical chest pain associated with ST segment depression of $>1 \mathrm{~mm}$ in the precordial leads. Patients with angina at rest or transient ST segment elevation during pain were excluded. No patient had a history of previous anterior myocardial infarction or showed abnormal $Q$ waves in the precordial leads. The results of physical examination were normal. Left ventricular angiography and coronary arteriography showed significant coronary disease (stenoses of the luminal diameter $>50 \%$ ) of the proximal portion of the left anterior descending artery in all 10 patients.

We studied patients within two weeks of coronary arteriography, without premedication, and at least three days after $\beta$ blockers had been progressively tapered and withdrawn. Withdrawal phenomena, such as accelerated angina or other acute coronary events, were not seen. Nifedipine and nitrates were discontinued for at least 12 hours. No patient was taking verapamil or diltiazem. We obtained the informed consent of all patients before the study.

\section{METHODS}

The study was performed late in the morning in supine fasting patients. A triple thermistor thermodilution catheter with pacing electrodes was introduced under local anaesthesia into an antecubital vein and advanced to the great cardiac vein. The position of the catheter was checked frequently by fluoroscopy during the procedure. Once the catheter was in position flow in the great cardiac vein while the patient was at rest was determined by a continuous infusion of a physiological saline solution $(56 \mathrm{ml} / \mathrm{min}$ for 30 seconds). Arterial blood pressure was recorded continuously by means of a Teflon cannula in a brachial artery. Blood samples for the measurement of haemoglobin oxygen saturation were obtained from an artery and the great cardiac vein of nine patients. The heart rate was then increased by coronary sinus pacing, which increased by 10 beats per minute until the patient experienced chest pain or ST segment depression $>2 \mathrm{~mm}$ developed in the anterior leads. Each pacing rate was maintained for two minutes. When the end point was reached, blood flow in the great cardiac vein was measured for 30 seconds in all patients and samples of arterial and great cardiac vein blood were again obtained in nine patients. A 12 lead electrocardiogram was recorded before and at the end of pacing, and leads V4, V5, and V6 were monitored throughout the test. After 40 minutes a bolus dose of gallopamil $(0.02 \mathrm{mg} / \mathrm{kg})$ was given intravenously over three minutes and this was followed by a continuous infusion of $0.0005 \mathrm{mg} / \mathrm{kg} / \mathrm{min}$. Ten minutes later baseline data were collected and atrial pacing was started again. When the patient experienced chest pain, when ST segment depression ( $>2 \mathrm{~mm}$ ) developed, or when a heart rate of 170 beats per minute was reached, the coronary haemodynamic measurements were repeated. Venous blood samples for measuring gallopamil concentrations were also obtained at that time. An intravenous bolus dose $(0.5 \mathrm{mg})$ of atropine was given to two patients in whom failure to capture occurred after gallopamil. No complications were observed during the pacing procedure.

Table 1 Clinical, haemodynamic, and angiographic data in 10 patients with stable exertional angina

\begin{tabular}{|c|c|c|c|c|c|c|c|}
\hline \multirow[b]{2}{*}{ Case No } & \multirow[b]{2}{*}{ Sex } & \multirow[b]{2}{*}{ Age } & \multirow{2}{*}{$\begin{array}{l}\text { LVEDP } \\
(\mathrm{mm} \mathbf{H g})\end{array}$} & \multirow[b]{2}{*}{$E F(\%)$} & \multicolumn{3}{|c|}{ Stenosis of } \\
\hline & & & & & $L A D$ & $C f x$ & $R C A$ \\
\hline $\begin{array}{r}1 \\
2 \\
3 \\
4 \\
5 \\
6 \\
7 \\
8 \\
9 \\
10\end{array}$ & $\begin{array}{l}M \\
M \\
M \\
M \\
M \\
M \\
F \\
M \\
M \\
M\end{array}$ & $\begin{array}{l}58 \\
60 \\
60 \\
50 \\
59 \\
49 \\
55 \\
52 \\
51 \\
50\end{array}$ & $\begin{array}{r}23 \\
13 \\
16 \\
24 \\
16 \\
7 \\
19 \\
12 \\
14 \\
12\end{array}$ & $\begin{array}{l}68 \\
59 \\
74 \\
69 \\
56 \\
84 \\
79 \\
82 \\
70 \\
78\end{array}$ & $\begin{array}{r}90 \% \\
75 \% \\
75 \% \\
100 \% \\
99 \% \\
99 \% \\
100 \% \\
75 \% \\
75 \% \\
75 \%\end{array}$ & $\begin{array}{l}\overline{-} \\
\overline{90} \% \\
\overline{90} \% \\
\overline{75} \% \\
\overline{75} \% \\
99 \%\end{array}$ & $\begin{array}{l}\bar{Z} \\
\bar{Z} \\
99 \% \\
75 \% \\
\bar{Z} \\
\overline{100} \% \\
99 \%\end{array}$ \\
\hline $\operatorname{Mean}(\mathrm{SD})$ & & $54(4)$ & $16(5)$ & $72(9)$ & & & \\
\hline
\end{tabular}

LVEDP, left ventricular end diastolic pressure; EF, ejection fraction; LAD, left anterior descending coronary artery; Cfx, circumflex; RCA, right coronary artery. 
Table 2 Resting values of haemodynamic variables in 10 patients with stable exertional angina

\begin{tabular}{|c|c|c|c|c|c|c|c|c|c|c|c|c|}
\hline \multirow[b]{2}{*}{ Case No } & \multicolumn{2}{|c|}{$\begin{array}{l}\text { Heart rate } \\
\text { (beats/min) }\end{array}$} & \multicolumn{2}{|c|}{$M A P(m m H g)$} & \multicolumn{2}{|c|}{$\begin{array}{l}\text { Double product } \\
(\mathrm{bpm} \times \mathrm{mm} \mathrm{Hg} \\
\left.\times 10^{-2}\right)\end{array}$} & \multicolumn{2}{|l|}{$\begin{array}{l}\text { GCVF } \\
(\mathrm{ml} / \mathrm{min})\end{array}$} & \multicolumn{2}{|c|}{$\begin{array}{l}A R C R \\
(\mathrm{~mm} \mathrm{Hg} / \mathrm{ml} / \mathrm{min})\end{array}$} & \multicolumn{2}{|c|}{$M \mathrm{MO}_{2}(\mathrm{ml} / \mathrm{min})$} \\
\hline & Control & $G P$ & Control & $G P$ & Control & $G P$ & Control & $G P$ & Control & $G P$ & Control & $G P \overline{\overline{\bar{C}}}$ \\
\hline $\begin{array}{r}1 \\
2 \\
3 \\
4 \\
5 \\
6 \\
7 \\
8 \\
9 \\
10\end{array}$ & $\begin{array}{r}71 \\
108 \\
73 \\
58 \\
82 \\
60 \\
113 \\
72 \\
70 \\
67\end{array}$ & $\begin{array}{r}75 \\
102 \\
85 \\
65 \\
76 \\
63 \\
103 \\
72 \\
66 \\
71\end{array}$ & $\begin{array}{l}129 \\
141 \\
120 \\
110 \\
134 \\
104 \\
129 \\
108 \\
100 \\
100\end{array}$ & $\begin{array}{r}121 \\
131 \\
102 \\
102 \\
117 \\
104 \\
96 \\
125 \\
96 \\
92\end{array}$ & $\begin{array}{r}139 \cdot 2 \\
209 \cdot 5 \\
124 \cdot 8 \\
93.4 \\
150 \cdot 9 \\
100 \cdot 2 \\
206 \cdot 8 \\
113.8 \\
114 \cdot 1 \\
91.8\end{array}$ & $\begin{array}{c}137 \cdot 2 \\
191 \cdot 8 \\
120 \cdot 7 \\
92 \cdot 9 \\
130 \\
92 \\
141 \cdot 1 \\
116 \cdot 6 \\
101 \cdot 6 \\
94 \cdot 4\end{array}$ & $\begin{array}{r}58 \cdot 8 \\
104.3 \\
93.5 \\
43 \cdot 2 \\
91 \cdot 3 \\
52 \cdot 8 \\
52 \cdot 8 \\
82.4 \\
45 \cdot 6 \\
56.9\end{array}$ & $\begin{array}{c}63 \cdot 4 \\
104 \cdot 3 \\
89 \cdot 8 \\
36 \cdot 9 \\
62 \cdot 3 \\
58 \\
30 \\
128 \cdot 7 \\
50 \cdot 3 \\
43 \cdot 9\end{array}$ & $\begin{array}{l}2 \cdot 19 \\
1 \cdot 35 \\
1 \cdot 28 \\
2 \cdot 54 \\
1.47 \\
1.97 \\
2 \cdot 44 \\
1 \cdot 31 \\
2 \cdot 19 \\
1 \cdot 76\end{array}$ & $\begin{array}{l}1 \cdot 9 \\
1.25 \\
1 \cdot 13 \\
2 \cdot 76 \\
1.88 \\
1 \cdot 79 \\
3.2 \\
0.97 \\
1.91 \\
2 \cdot 1\end{array}$ & $\begin{array}{r}5 \cdot 3 \\
13 \cdot 1 \\
9.7 \\
6 \cdot 9 \\
12 \cdot 6 \\
6.9 \\
6 \cdot 8 \\
10 \\
6.8\end{array}$ & 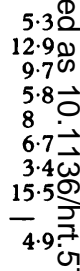 \\
\hline $\begin{array}{l}\text { Mean } \\
\text { (SD) }\end{array}$ & $\begin{array}{c}77 \\
(19)\end{array}$ & $\begin{array}{r}78 \\
(14)\end{array}$ & $\begin{array}{l}117 \\
(15)\end{array}$ & $\begin{array}{l}109 \\
(14)\end{array}$ & $\begin{array}{l}134 \cdot 4 \\
(43 \cdot 2)\end{array}$ & $\begin{array}{l}121 \cdot 8 \\
(30 \cdot 7)\end{array}$ & $\begin{array}{l}68 \cdot 2 \\
(22)\end{array}$ & $\begin{array}{l}66 \cdot 8 \\
(31)\end{array}$ & $\begin{array}{l}1 \cdot 85 \\
(0.5)\end{array}$ & $\begin{array}{l}1 \cdot 89 \\
(0 \cdot 7)\end{array}$ & $\begin{array}{l}8 \cdot 7 \\
(3)\end{array}$ & $\begin{array}{l}8 \\
(4)\end{array}$ \\
\hline
\end{tabular}
GP, gallopamil.

There were no significant differences between control and gallopamil values.

CALCULATIONS AND STATISTICAL ANALYSIS Great cardiac vein flow was calculated by thermodilution method by the formula:

$$
\operatorname{GCVF}(\mathrm{ml} / \mathrm{min})=V_{i} \times\left(\frac{T_{b}-T_{i}}{T_{b}-T_{m}}-1\right) \times 1.08
$$

where GCVF = great cardiac vein flow, $V_{i}$ is the indicator rate of injection $(56 \mathrm{ml} / \mathrm{min}), T_{b}$ is blood temperature, $T_{i}$ is the temperature of injectate, and $T_{m}$ is the temperature of the mixture of great cardiac vein blood and injectate; 1.08 is a constant related to the indicator.

Mean arterial pressure was measured by electronic filtration of the pressure curve and anterior regional coronary resistance was calculated as

$$
\operatorname{ARCR}(\mathrm{mm} \mathrm{Hg} / \mathrm{ml} / \mathrm{min})=\frac{\text { MAP }}{\mathrm{GCVF}}
$$

where $\mathrm{ARCR}=$ anterior regional coronary resistance, $\mathrm{MAP}=$ mean arterial pressure, GCVF $=$ great cardiac vein flow.

Anterior regional myocardial oxygen consumption was derived as (arterial oxygen content minus great cardiac vein oxygen content) $\times$ great cardiac vein flow. Heart rate was calculated from the electrocardiogram. Plasma gallopamil concentrations were measured by high performance liquid chromatography.

Statistical analysis was performed by Student's paired $t$ test. All data are expressed as mean (SD).

\section{Results}

HAEMODYNAMIC AND ANGIOGRAPHIC FINDINGS

Four patients had disease of the proximal left ante-

\begin{tabular}{|c|c|c|c|c|c|c|c|c|c|c|c|c|}
\hline \multirow[b]{2}{*}{ Case No } & \multicolumn{2}{|c|}{$\begin{array}{l}\text { Heart rate } \\
\text { (beats } / \text { min) }\end{array}$} & \multicolumn{2}{|c|}{$M A P(m m H g)$} & \multicolumn{2}{|c|}{$\begin{array}{l}\text { Double product } \\
(\text { bpm } \times m m ~ H g \\
\left.\times 10^{-2}\right)\end{array}$} & \multicolumn{2}{|c|}{$G C V F(\mathrm{ml} / \mathrm{min})$} & \multicolumn{2}{|c|}{$\begin{array}{l}A R C R \\
(\mathrm{~mm} \mathrm{Hg} / \mathrm{ml} / \mathrm{min})\end{array}$} & \multicolumn{2}{|c|}{$M V o^{2}(\mathrm{ml} / \min$ 至. } \\
\hline & Control & $G P$ & Control & $G P$ & Control & $G P$ & Control & $G P$ & Control & $G P$ & Control & GPఠூ \\
\hline $\begin{array}{r}1 \\
2 \\
3 \\
4 \\
5 \\
6 \\
7 \\
8 \\
9 \\
10\end{array}$ & $\begin{array}{l}130 \\
150 \\
150 \\
120 \\
150 \\
140 \\
160 \\
160 \\
120 \\
140\end{array}$ & $\begin{array}{l}140 \\
160 \\
160 \\
150 \\
160 \\
170 \\
170 \\
160 \\
140 \\
160\end{array}$ & $\begin{array}{l}165 \\
143 \\
118 \\
137 \\
137 \\
133 \\
125 \\
146 \\
108 \\
117\end{array}$ & $\begin{array}{r}137 \\
133 \\
110 \\
110 \\
125 \\
96 \\
92 \\
142 \\
108 \\
108\end{array}$ & $\begin{array}{l}297 \cdot 7 \\
291 \\
238 \cdot 5 \\
216 \\
274 \cdot 5 \\
256 \cdot 2 \\
273 \cdot 6 \\
307 \cdot 2 \\
200 \cdot 4 \\
221 \cdot 2\end{array}$ & $\begin{array}{l}268 \cdot 8 \\
288 \\
235 \cdot 2 \\
220 \cdot 5 \\
267 \cdot 2 \\
227 \cdot 8 \\
227 \cdot 8 \\
280 \\
221 \cdot 2 \\
233 \cdot 6\end{array}$ & $\begin{array}{c}125 \cdot 8 \\
146 \cdot 3 \\
149 \cdot 1 \\
59 \cdot 8 \\
186 \cdot 6 \\
171 \cdot 9 \\
63.8 \\
236 \\
73.5 \\
128.6\end{array}$ & $\begin{array}{r}125 \cdot 8 \\
141 \cdot 1 \\
135 \cdot 8 \\
45 \cdot 2 \\
102 \cdot 6 \\
138 \cdot 4 \\
80 \cdot 7 \\
176 \cdot 3 \\
84.6 \\
98 \cdot 6\end{array}$ & $\begin{array}{l}1.31 \\
0.97 \\
0.79 \\
2.29 \\
0.73 \\
0.77 \\
1.96 \\
0.62 \\
1.47 \\
0.91\end{array}$ & $\begin{array}{l}1.08 \\
0.94 \\
0.81 \\
2.43 \\
1.22 \\
0.69 \\
1 \cdot 14 \\
0.81 \\
1.28 \\
1 \cdot 1\end{array}$ & $\begin{array}{l}10 \cdot 7 \\
17 \\
16 \cdot 6 \\
9 \cdot 3 \\
22 \cdot 8 \\
20 \cdot 1 \\
7 \cdot 4 \\
26 \cdot 9 \\
- \\
14\end{array}$ & 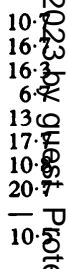 \\
\hline $\begin{array}{l}\text { Mean } \\
\text { (SD) }\end{array}$ & $\begin{array}{l}142 \\
(15)^{\star}\end{array}$ & $\begin{array}{l}158 \\
(11)^{\star}\end{array}$ & $\begin{array}{l}133 \\
(17) \dagger\end{array}$ & $\begin{array}{l}116 \\
(17) \dagger\end{array}$ & $\begin{array}{l}257 \cdot 6 \\
(37 \cdot 1)\end{array}$ & $\begin{array}{l}247 \\
(26)\end{array}$ & $\begin{array}{l}134 \cdot 1 \\
(57)\end{array}$ & $\begin{array}{l}112 \cdot 9 \\
(38)^{\circ}\end{array}$ & $\begin{array}{l}1 \cdot 18 \\
(0.6)\end{array}$ & $\begin{array}{l}1 \cdot 15 \\
(0 \cdot 5)\end{array}$ & $\begin{array}{l}16 \cdot 1 \\
(6)\end{array}$ & (4) $\frac{\text { (D) }}{\mathrm{D}}$ \\
\hline
\end{tabular}

Table 3 Peak pacing values of haemodynamic variables in 10 patients with stable exertional angina 


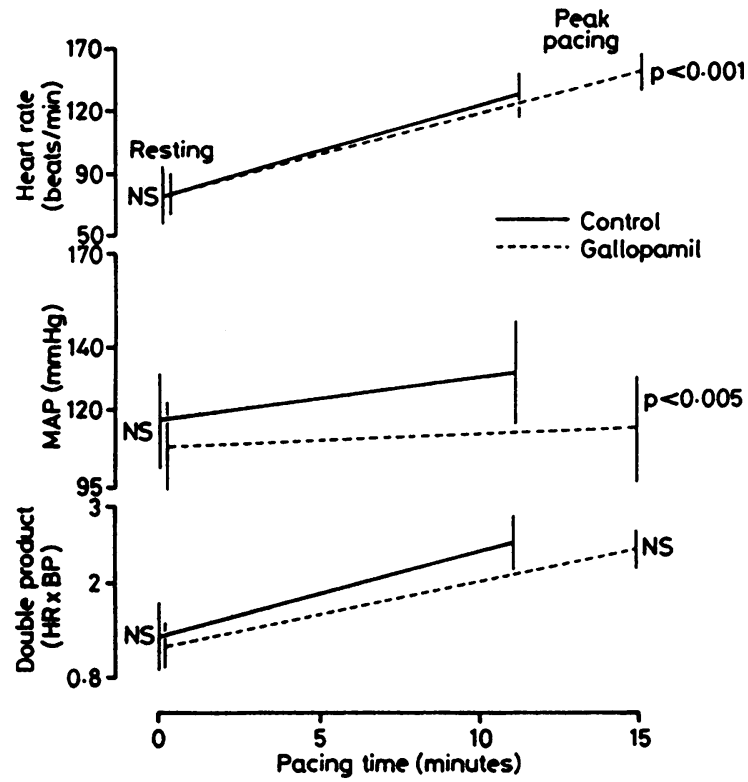

Fig 1 Effects of gallopamil on heart rate, mean arterial pressure (MAP), and double product in 10 patients with stable exertional angina. Resting and peak pacing values are shown. No difference was observed at rest whereas heart rate increased and mean arterial pressure decreased at peak pacing after gallopamil had been given. As a result the double product remained unchanged; however, pacing was tolerated for longer after gallopamil.

rior descending artery only, three had double vessel, and three had triple vessel disease (table 1$)$. The mean ejection fraction was $0.72(0.09)$ and the mean left ventricular end diastolic pressure was $16(5)$ $\mathrm{mm} \mathrm{Hg}$.

HAEMODYNAMIC AND METABOLIC EFFECTS OF GALLOPAMIL AT REST (TABLE 2)

The heart rate was unchanged after administration of the drug (77(19) vs 78(14) beats/min, $\mathrm{p}=\mathrm{NS}$ ). Mean arterial pressure fell in all but one patient (case no 8); however, the difference did not reach statistical significance (117(15) vs 109 (14) $\mathrm{mm} \mathrm{Hg}$ ). As a consequence the double product decreased slightly and not significantly $(134(42)$ vs $122(31)$ beats $\left./ \mathrm{min} \times \mathrm{mm} \mathrm{Hg} \times 10^{-2}\right)$, as did anterior regional myocardial oxygen consumption $(8 \cdot 7(3)$ vs 8.0 (4) $\mathrm{ml} / \mathrm{min}, \mathrm{p}=\mathrm{NS}$ ). No significant change was found in blood flow in the great cardiac vein $(68.2(22)$ vs $66.8(31) \mathrm{ml} / \mathrm{min})$ or anterior regional coronary resistance $(1.85(0.5)$ vs $1.89(0.7)$ $\mathrm{mm} \mathrm{Hg} / \mathrm{ml} / \mathrm{min}$ ).
HAEMODYNAMIC AND METABOLIC EFFECTS OF GALLOPAMIL AT PEAK PACING

(TABLE 3)

The end points of the coronary sinus pacing were angina in seven patients and ST segment depression of $>2 \mathrm{~mm}$ without pain in the remaining three. After gallopamil only four patients complained of angina, five patients showed asymptomatic ST segment depression of $>2 \mathrm{~mm}$, and in one (case 6) pacing was stopped after the maximal pacing rate had been maintained for two minutes. In all but one patient (case 8) end points were reached at higher pacing rate after gallopamil (control 142(15), gallopamil $158(11)$ beats/min, $p<0.001)$. As a result gallopamil increased mean pacing time from $11.0(2.6)$ to $14.8(2.4)$ minutes $(\mathrm{p}<0.001)$ while maximal ST segment depression decreased from 1.9 $(0.5)$ to $1.6(0.7) \mathrm{mm}(p=N S)$.

As mean arterial pressure decreased from $133(17)$ to $116(17) \mathrm{mm} \mathrm{Hg}$ ( $p<0.005$ ) the peak pacing double product was slightly but not significantly reduced (fig 1 ). There was no significant change in great cardiac vein flow or in anterior regional coronary resistance (fig 2). Anterior regional myocardial oxygen consumption was also unchanged after gallopamil (from 16.1 (6) to $13 \cdot 7(4) \mathrm{ml} / \mathrm{min}, \mathrm{p}=\mathrm{NS}$ ).

The mean plasma concentration of gallopamil at peak pacing was $41.4(13.8) \mathrm{ng} / \mathrm{ml}$.

\section{Discussion}

Gallopamil is a new calcium antagonist with the structure of a phenylalkilamine derivative, like vera-

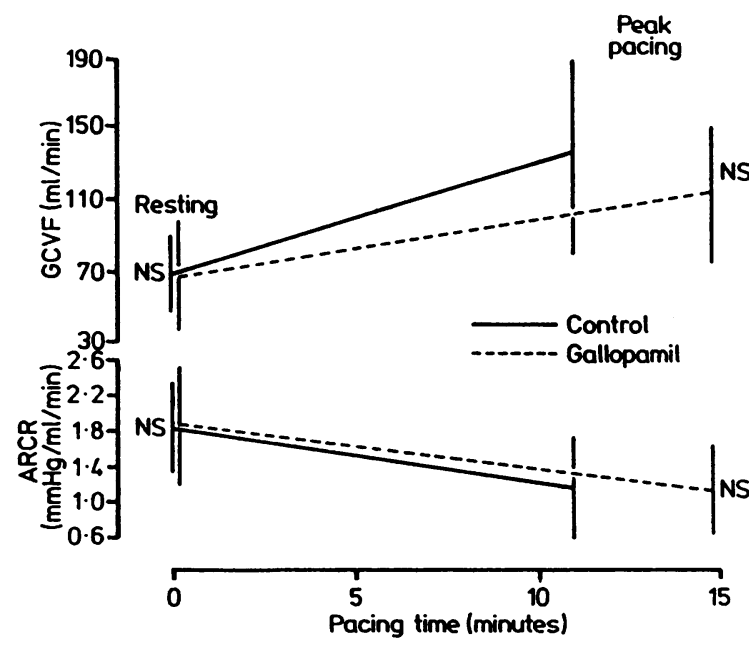

Fig 2 Effects of gallopamil on great cardiac vein flow (GCVF) and anterior regional coronary resistance ( $A R C R$ ) at rest and at peak pacing. No significant change was seen between resting values or peak pacing values. 
pamil. It has the same electrophysiological properties as verapamil, but is three to five times as potent on a weight for weight basis. ${ }^{14}$ Oral gallopamil was as effective or more effective than propranolol in improving the exercise tolerance of patients with stable exertional angina after short term ${ }^{11}$ and after long term administration. ${ }^{10}$ Moreover, the drug is well tolerated; few adverse effects were reported after long term oral treatment. ${ }^{10}$

The mechanism by which this drug exerts its beneficial effects has yet to be established. After long term oral administration Khurmi et al found that the rate-pressure product at peak exercise was higher than after placebo. ${ }^{10}$ Because the degree of ST segment depression was unchanged these workers suggested that the greater exercise capacity induced by gallopamil was the result of improved myocardial oxygen supply. By contrast, Rettig and Sen found that the double product did not increase at the end of exercise, either after short term or after long term oral administration. ${ }^{12}$ Similarly, Scrutinio et al reported that the rate-pressure product was not modified at maximal workload ${ }^{11}$; this suggests that the drug may improve exercise capacity by reducing oxygen demand.

In our study short term intravenous administration of gallopamil improved pacing tolerance, confirming the antianginal activity of the drug. Because all patients had a proximal lesion of the left anterior descending artery we measured blood flow in the great cardiac vein, which is a reliable index of blood flow through that artery, ${ }^{131516}$ to assess haemodynamic changes in the area of the myocardium in which perfusion was jeopardised. Gallopamil did not increase blood flow in the great cardiac vein either at rest or at peak atrial pacing. Thus the beneficial effect of the drug does not seem to be related to increased perfusion of ischaemic regions. Moreover, myocardial oxygen consumption in the anterior region was similar at the peaks of the two pacing periods despite the higher heart rate that was achieved after gallopamil infusion. This suggests that the mechanism of action of the drug was a reduction in myocardial metabolic demand. Because most of our patients had multivessel disease, however, we cannot exclude the possibility that gallopamil increased blood flow to the non-anterior, yet potentially ischaemic myocardium and that such increase contributed to the improved performance induced by the drug. This possibility, however, seems remote, because the double product, a reflection of the maximal rate at which the obstructed coronary arteries deliver oxygen, was unchanged at peak pacing after gallopamil.

In conclusion, our data confirm that gallopamil is an effective antianginal drug that may well prove to be a useful addition to current treatment of angina $\vec{C}$ pectoris. A reduction of myocardial oxygen con- $\vec{\Rightarrow}$ sumption seems to be the predominant mechanism by which the drug exerts its beneficial effects.

\section{References}

1 Bala Subramanian V, Millar-Craig MW, Davies AB, Raftery EB. Verapamil therapy in variant angina: assessment by high-fidelity frequency modulated ambulatory ECG. Am Heart f 1981;101:849-50.

2 Bala Subramanian V, Paramasivan R, Lahiri A, Raftery of EB. Verapamil in chronic stable angina: a controlled study with computerised treadmill exercise. Lancet in $1980 ; \mathbf{i}: 841-4$.

3 Bala Subramanian V, Bowles M, Lahiri A, Davies AB, Raftery EB. Long-term antianginal action of verapamil assessed with quantitated serial treadmill stress testing. Am f Cardiol 1981;48:529-35.

4 Antman E, Muller J, Goldberg S, et al. Nifedipine therapy for coronary-artery spasm. Experience in 127 patients. N Engl F Med 1980;302:1269-73.

5 Previtali M, Salerno JA, Tavazzi L, et al. Treatment of angina at rest with nifedipine: a short-term controlled study. Am f Cardiol 1980;45:825-30.

6 Specchia G, De Servi S, Falcone C, et al. Effects of nifedipine on coronary hemodynamic findings during exercise in patients with stable exertional angina. Circulation 1983;68:1035-43.

7 Pepine CJ, Feldman RL, Whittle J, Curry RC, Conti CR. Effect of diltiazem in patients with variant angina: a randomized double-blind trial. Am Heart $\mathcal{f}$ 1981;101:719-25.

8 Bala Subramanian V, Khurmi NS, Bowles MJ, O'Hara M, Raftery EB. Objective evaluation of three dose levels of diltiazem in patients with chronic stable angina. $f$ Am Coll Cardiol 1983;1:1144-53.

9 Hung J, Camb IH, Connolly SJ, Jutey KR, Goris ML, Schroeder JS. The effects of diltiazem and propranolol, alone and in combination, on exercise performance and left ventricular function in patients with stable effort angina: a double-blind, randomized and placebo-controlled study. Circulation 1983; 68:560-7.

10 Khurmi NS, O'Hara MJ, Bowles MJ, Bala Subramanian V, Raftery EB. Randomized double-blind 5 comparison of gallopamil and propranolol in stable angina pectoris. $A m \mathcal{F}$ Cardiol 1984;53:684-8.

11 Scrutinio D, Lagioia R, Accettura D, Preziusi N, Mastropasqua E, Rizzon P. Dose-response effectiveness of gallopamil for the treatment of chronic stable effort angina pectoris: comparison with propranolol. Curr Ther Res 1985;37:830-8.

12 Rettig G, Sen S. Acute and long-term effects of gal- T lopamil in patients with stable angina pectoris. In: Kaltenbach M, Hopf R, eds. Gallopamil. Pharmacological and clinical profile of a calcium antagonist. Berlin, Heidelberg, New York, Tokyo: SpringerVerlag, 1984:136-42. 
13 Roberts DL, Nakazawa HK, Klocke FJ. Origin of great cardiac vein and coronary sinus drainage within the left ventricle. Am f Physiol 1976;230:486-92.

14 Fleckenstein A, Fleckenstein B, Spah F, Byon YK. Gallopamil (D-600)-a calcium antagonist of high potency and specificity. Effects on the myocardium and pacemakers. In: Kaltenbach $\mathbf{M}$, Hopf $\mathbf{R}$, eds. Gallopamil. Pharmacological and clinical profile of $a$ calcium antagonist. Berlin, Heidelberg, New York,
Tokyo: Springer-Verlag, 1984:1-32.

15 Ganz W, Tamura K, Marcus HS, Donoso R, Yoshida S, Swan HJC. Measurement of coronary sinus blood flow by continuous thermodilution in man. Circulation 1971;44:181-95.

16 Pepine CJ, Metha J, Webster WW Jr, Nichols WW. In vivo validation of a thermodilution method to determine regional left ventricular blood flow in patients with coronary disease. Circulation 1978;58:795-802. 